Pregledni naučni članak Primljen: 30.05.2016. Odobren: 09.06.2016.

\title{
GLOBALIZACIJA I DEFICITI I OGRANIČENJA GLOBALNOG UPRAVLJANJA
}

Karakter i dinamika odnosa u međunarodnoj politici, u kojoj je sve snažniji povratak na realpolitičke sadržaje u spoljnopolitičkom delovanju velikih sila, nedvovosmisleno potvrduju da globalizacija ne radi, da jenjava njena snaga i da je sve manje kredibilan koncept uređenja savremenog svetskog društva. Globalni finansijski kolaps koji je pogodio svet 2008. godine predstavlja uverljiv pokazatelj da je veći deo globalizacije diskreditovan, a vera u jedno čovečanstvo je sve manje poželjan koncept.

Istovremeno, sa porastom pitanja koja zahtevaju globalno rešavanja sve su brojnije ljudske delatnosti koje podrazumevaju jedinstvenu ili medunarodnu regulaciju. Svet je sve više jedna homeostataska celina međuzavisnih delova gde su mnogi aspekti granica između država teško održivi ili čak nemogući. Otuda značaj globalnih faktora, od kojih će u punoj meri zavisiti artikulacija individualnog i zajedničkog života ljudi u budućnosti, apostrofiraju pitanja zajedničkog upravljanja koje treba da obezbedi globalni mir i bezbednost i pospeši blagostanje širom sveta na jedan univerzalno prihvatljiv i efikasna način

Zbog toga, ispoljene suštinske manjkavosti globalnog upravljanja svetom, iako su obeshrabrile veru u jedno čovečanstvo, one nisu umanjile objektivnu potrebu globalnog pristupa mnogima sadržajima savremene egzistencije ljudi. Mnogi aspekti bezbednosti, počev od bezbednosti pojedinca pa do energetske i ekološke bezbednosti u savremenim uslovima nisu zamislivi bez internacionalnog pristupa. Medutim globalno upravljanje bezbednošću povezano je sa brojnim ograničenjima i izazovima.

Ključne reči: globalizacija, svetsko društvo, ograničenja globalnog upravljanja svetom, svetsko društvo rizika, globalno upravljanje bezbednosti.

\footnotetext{
* Redovni profesor, Institut za strategijska istraživanja, Beograd e-mail: stanislav.stojanovic@mod.gov.rs

** Redovni profesor, Pravni fakultet, Univerzitet „Džon Nezbit”, Beograd e-mail: ndanilovic@naisbitt.edu.rs
} 


\section{Uvod}

Savremena globalizacija spada u red najpopularnijih koncepata stvaranja jedinstvene zajednice čovečanstva koji je pobudio ogromna očekivanja i podstakao ogromnu energiju. Aspiracija za jedinstvenim upravljanjem svetom stara je koliko i sam svet i kontinuitet globalnih političkih stremljenja može se pratiti od najranijih početaka društvene istorije čovečanstva. Međutim, nikada do sada jedna ideja koja ima za cilj geografsko i političko objedinjavanje sveta nije imala takvu snagu i zavodljivost kao što je to slučaj sa savremenom globalizacijom.

Zagovornici globalizacije tvrdili su da je trijumf Zapada u hladnoratovskom nadmetanju potvrdio superiornost liberalnog modela i da taj trijumf istovremeno predstavlja raskid sa realpolitičkom percepcijom međunarodne politike. $\mathrm{Na}$ taj način, kako se tvrdilo, stvorene su pretpostavke da društva širom sveta, otpočnu sopstvenu rekonstrukciju i kroz prizmu neoliberalne ekonomske škole definišu nove pravce društvenog razvoja. Najavljen je proces globalnog zbližavanja, stvaranja globalne kulture i univerzalizacije demokratskoog upravljanja, trajno prevazilaženje rata i uspostavljanje trajnog mira. Ta misija stvaranja globalnog društva u kome ekonomske sile definišu sve ostale društvene sadržaje deklarisana je kao neizbežnost i neminovnost.

Danas je evidentno da se društvena i politička realnost nije razvijala onako kako su to zagovornici glbalizacije bili najavljivali na početku poslednje decenije dvadestog veka. Izuzetna tehnološka dostignuća ne mogu da ublaže poržavajuće neuspehe i bolne posledice gobalizacije koje otvaraju prostore dugotrajne nestabilnosti sveta i socijalnog, ekonomskog i političkog bespuća njegovog razvoja. Sve je očiglednije da je ishod globalnih procesa snažno demantovao, istinom o neizbežnosti ekonomskog teorijskog koncepta čija je ambicija bila da preoblikuje političke, ekonomske i socijalne oblasti savremenih društava. Svet je zapao u doba konfuzije, nesigurnosti i nebezbednosti, prerastajući u društvo rizika. Ekonomske krize i finansijska nestabilnost diskerditovali su ideju globalnog tržišta, a nejednakost i siromaštvo su desocijalizovali prostor koji je dostigao planetarne razmere. Snažno približavanje naroda, političkih zajednica i kultura i intenziviranje njihove međuzavisnosti podstaklo je i sve intenzivnije razilaženje, pojavu novih nacionalnih modela, radikalizujući indentitetska određenja do najrazornijih formi. Sve je izvesnije vraćanje konceptu sveta u kome realpolitički instrumenti postaju preovalađujući, čime se poništava optimizam o odnosima u međunarodnoj politici.

Istovremeno, globalizacija, pre svega njeni tehnološki dometi, je uvećala broj problema koji traže globalni angažman i umnožila je delatnosti koje zahtevaju međunarodno regulisanje. Transnacionalno ugrožavanje bezbednosti, pre svih: terorizam, oružje za masovno uništavanje, organizovani kriminal, ekološka degradacija i demografska eksplozija, kao i praksa da se nadnacionalne bezbednosne asocijacije i oružane snage najmoćnijih država sveta često angažuju 
suprotno pravilima međunarodnog pravnog poretka koja definišu upotrebu sile u međunarodnim odnosima su samo deo fenomena savremene realnosti koji traže globalni pristup. Otuda, ispoljene suštinske manjkavosti globalnog upravljanja svetom, iako su obeshrabrile veru u jedno čovečanstvo, nisu umanjile objektivnu potrebu globalnog pristupa mnogima sadržajima savremene egzistencije ljudi na planeti Zemlji.

\section{Deficiti upravljanja svetskim društvom rizika}

Analiza savremene međunarodne politike upućuje na zaključak da je neodrživo, svojevremeno ošteprihvaćeno mišljenje, da će svet sa globalizacijom postati racionalniji i bezbedniji i da će se na taj način, istorijski ciklusi mira i ratova prekinuti, odnosno, da će istorija biti mrtva. ${ }^{1}$ Pokazalo se da se nisu obistinile tvrdnje onih koji su globalizaciju najavljivali kao formulu za obezbeđenje harmonije ekonomskog i političkog razvoja globalnog društva, kao i progresa, mira i međunarodnih odnosa zasnovanih na saradnji. Danas je sasvim jasno da je «paradigma jednog harmoničnog sveta» isuviše daleko od stvarnosti².

Promene izazvane procesom globalizacije inicirale su rizike zbog kojih postaju sve manje značajni prostor, vreme i granice između država i kontinenata i čiji se tokovi i posledice sve teže mogu predvideti i kontrolisati. Na taj način savremeni svet sve više postaje globalno društvo rizika ${ }^{3}$. Naime, u svim istorijskim tipovima društva postojalo je iskustvo opasnosti, ali su rizici vezani za deteritorijalizovan prostor koji u procesu globalizacije postaje sve manje nacionalan, a sve više globalan fenomen. Bek u vezi s tim pravilno zaključuje: «Rizici modernizacije poseduju jednu imanentnu tendenciju ka globalizaciji» ${ }^{4}$, a sve snažnija i intenzivnija međuzavisnost društava i političkih zajednica, kako misli Habermas, doprinosi da svetsko «stanovništvo je objektivno odavno uključeno u nedobrovoljnu zajednicu rizika» ${ }^{5}$.

Teza teoretičara neoliberalne koncepcije, da će svet ući u period miroljubivih odnosa kroz transnacionalnu ekonomsku saradnju i demokratizaciju političkog prostora, pokazala se kao neosnovana. Danas nije sporno da globalnim trijumfom demokratije i slobodnog tržišta nije nužno donet mir i stabilnost svetu. Naglašavajući primarni značaj ekonomskog faktora, neoliberalizam je marginalizovao i potisnuo sve druge principe socijalne organizacije, a funkcionisanje slobodnog tržišta neizbežno je kreiralo ambijent globalnog porasta asocijalnih

Sol R. Džon (2011): Propast globalizma i preoblikovanje sveta, Arhipelag, Beograd, 24.

Hantington Semjuel (1999): uel, Sukob civilizacija i preoblikovanje svetskog poretka, CID, Podgorica, 33.

3 Videti više u: Bek Urlix (2001), Rizično društvo, Filip Višnjić, Beograd.

Ibid, 55.

Habermas Jirgen (2002): Postnacionalna konstelacija, OTKROVENJE, Beograd, 62.

Vol. 13, № 2, 2016: 133-148 
društvenih odnosa, što je uticalo da nepoverenje i animozitet različitih sadržaja budu dominatna obeležja savremenog svetskog društva. Posebno dramatičan aspekt savremene svetske realnosti predstavlja nezaustavljivi porast nejednakosti i siromaštva, što uslovljava mnoštvo podela širom sveta i dramatično povećava njegovu nestabilnost.

Projekcije demografskog rasta i transnacionalne tendencije potrošnje, odnosno perspektiva sve većeg nesklada između stanovništva i raspoloživih prirodnih resursa, dodatno uvećava potencijal za nastanak velikih socijalnih poremećaja i nestabilnosti sveta. Novi demografski profili u razvijenom svetu i svetu u razvoju i regionalne nejednakosti, kao najkritičniji aspekt demografskog buma, osnova su daljeg jačanja globalnih dezintegracionih procesa. U takvim okolnostima, pod uticajem socijalnih efekata demografskog buma, umnogome se oblikuje kontekst unutar kojeg rasne, verske i ideološke suprotnosti, kao i talasi migracija mogu da poprime teško kontrolisane dimenzije, što potvrđuje enormno veliki broj migranata iz severne Afrike, bliskog i srednjeg istoka koji želi da ostvare azil u zemljama Zapadne Evrope.

Suprotno predviđanjima zagovornika globalne uniformnosti o skorom uspostavljanju univerzalnih interesa i vrednosti čovečanstva, nacionalne kulture pokazuju novu vitalnost i snagu, pa je borba za nacionalni, verski i civilizacijski identitet postala jedan od glavnih rizika bezbednosti i najvažniji izvor sukoba i polarizacije posle «hladnog rata». Proces univerzalizacije osnovnih vrednosti i globalne povezanosti, praćen socijetalnom denacionalizacijom i diskreditovanjem i diskvalifikovanjem kulturnog nasleđa i tradicija, podstakao je ekspanziju brojnih tradicionalističkih pokreta i političkog budjenja potisnutih kolektiviteta i populacija. Nejednakost, siromaštvo i politička obespravljenost moćan su činilac takvih tendencija i generisanja etničkih animoziteta i sukoba. Otuda, jačanje pokreta radikalnih islamista, kao dominantnog nosioca retradicionalizacije i fanatizovane religioznosti, za Kejgana, predstavlja najdramatičnije opovrgavanje paradigme približavanja, ,jer je upravo približavanje, uključujući u to i koncept univerzalnih vrednosti, ono što radikalni islamisti odbacuju”. Za njega otpor koji islamisti pružaju prihvatanju zapadnih vrednosti ne predstavlja novu pojavu, ali upozorava da taj otpor danas zadobija novu i potencijalno kataklizmičnu dimenziju?

$6 \quad$ Kejgan Robert (2009): Povratak istorije i kraj snova, Centar za civilno-vojne odnose, Beograd, 78.

7 Isključivost stavova radikalnih islamista ukazuje da je svet suočen s perspektivom dugotrajnog sukoba islamista sa savremenm svetom. Kejgan posebno upozorava da velike sile nisu ni spremne niti sposobne da se efikasno ujedine u borbi protiv opasnosti koja nosi ekstremni islamistički pokret. Njihove sukobljene nacionalne ambicije, transatlanska neslaganja oko upotrebe moći, demokratije i autokratije, čini sve izraženijim njihove raskole u pristupu međunarodnoj politici i podriva njihovu volju za saradnjom. Zato je, kako zaključuje Kejgan, ideja o „istinskoj strateškoj saradnji SAD i Rusije, ili SAD i Kine u ratu protiv terorizma uglavnom fikcija”. Ibid, 82. 
Neoliberalni koncept je, insistirajući na ideji da vlast prepusti ekonomiju njenim mehanizmima, podstakao snažan proces marginalizacije države i eroziju njenih kapaciteta u obezbeđenju socijalne sigurnosti, bezbednosti i zaštite njenih građana, što su njene osnovne funkcije. Proces tranzicije države ka «liberalizmu» odvijao se neosetno, skrivajući svoje dugoročne posledice, koje se najsnažnije manifestuju u povećanju društvene patologije i njenoj transnacionalizaciji. Tako globalni terorizam, organizovani transnacionalni kriminal, korupcija i proliferacija oružja za masovno uništenje, kao posledica socijalne denacionalizacije i slabljenja zaštitnih sposobnosti nacionalnih država, postaju sve izraženiji i izazivaju globalni osećaj nesigurnosti, kreirajući nove mogućnosti i nove koncepte organizovanog kolektivnog nasilja u doba globalizacije ${ }^{8}$.

Terorizam je u uslovima globalizovanog sveta poprimio globalne razmere, prerastajući u alarmantnu vrstu nasilja i sveopšte nesigurnosti i ugroženosti ${ }^{9}$. Njegova eskalacija u poslednjoj deceniji 20. veka i prve dve decenije 21. veka, kao posledica neodgovarajućeg upravljanja svetom, najveća je opasnost po globalnu bezbednost, jer po razmerama, načinu na koji deluje i teškoćama da se ograniči, kontroliše i eliminiše, globalni terorizam prevazilazi dosada poznate forme terorističkih aktivnosti i osporava ideju bezbednosti koja je nastala u moderno doba $^{10}$. Kompleksnost strukture modernog društva, rizici marginalizacije, različite forme i interpretacije socijalnog iskustva i teškoće vezane za integraciju u postojeću distribuciju rada čine, ogroman potencijal za teroristički motivisane aktivnosti i širok spektar smrtonosnog nasilja.

Kritičan aspekt narušene globalne bezbednosti čine i sve izraženiji deteritorijalizovani ekološki poremećaji, kao i neslaganja oko raspodele odgovrnosti najmoćnijih država na zaustavljanju takvih trendova. U uslovima globalne povezanosti, ekološki problemi prevazilaze vremenska i prostorna ograničenja, pa degradacija ljudske okoline poprima obrise megaopasnosti i postaje sve teže rešiv bezbednosni problem savremenog sveta. Globalni karakter zagađenja životne sredine i pretvaranje prirodnih resursa u robu i tržišni proizvod alarmantno upozoravaju da su ekološki problemi postali prvorazredni problem bezbednosti. Isto tako, nadmetanja za prirodne resurse, posebno za vodu, koja će tokom narednih godina biti opterećena globalnim zagrevanjem, stvaraće uslove za nove antagonizme u međunarodnim odnosima. Prema procenama mnogih eksperata klimatskih promena, najveći bezbednosni rizici u budućnosti biće sukobi oko izvora vode za piće.

8 Cirn Michael (2013): «Globalization and global governance», Handbook of International relations, Edited by W.Carlsnaes, T. Risse, B.A.Simmons, SAGE, London, p. 401/427

9 Stojanović Stanislav(2009): Globalizacija i bezbednosne perspektive sveta, VIZ, Beograd, 260.

$10 \quad$ Falk Ričard (2012): „Globalna vlast (nove) zamisli”, u: Babić Jovan, Bojanić Petar, Zbornik Globalno upravljanje svetom, Pravni fakultet Univerziteta u Beogradu, Dosije studio, Beograd, 50. 
Koncept kooperativne bezbednosti i pluralističke bezbednosne zajednice (Dojč, Barnet, Adler) koji su najavljivani kao nova paradigma u mišljenju i praktikovanju bezbednosti iako su imali snažan uticaj na internacionalizaciju pitanja bezbednost i afirmaciju stava o nedeljivosti bezbednosti, oni ipak nisu zadobili univerzalni kredibilitet i postali opšteprihvaćena polazišta u bezbednosnom organizovanju savremnih društava ${ }^{11}$. Potreba SAD za sveprisutnom vojnom dominacijom i njena globalno agresivna koncepcija bezbednosti ${ }^{12}$ čija su najsnažnija obeležja inžinjring konflikata, preventivno ratovanje i voluntaristički pristup vojnom intervencionizmu, obezvredili su neke od nosećih odredjenja koncepta kooperativne bezbednoszti i bezbednosne zajednice koji prevashodno podrazumevaju negaciju tradcionalističkih pogleda na bezbednost.

Jačanje moći nadnacionalnih bezbednosnih asocijacija i vojnih efektiva ne samo najmoćnijih aktera u međunarodnoj politici osporili su najavu zagovornika globalnog društva o anahronizmu vojne sile. Posebno snažno podozrenje izaziva prisustvo nadnacionalnih bezbednosnih asocijacija u međunarodnoj politici, jer poznato je da što je moć veća, teže je kontrolisati. Odsustvo jasnih procedura demokratski utemeljene kontrole $\mathrm{u}$ angažovanju nadnacionalnih bezbednosnih efektiva pitanje je koje izaziva brojne neizvesnosti. Isto tako, bezbednosna zajednica država članica NATO-a i EU koje se navode kao primeri uspešnog modela bezbednosnog organizovanja savremenih društava, takođe nameće snažne nedoumice. Naime, širenjem NATO-a i nastojanjima koja imaju za cilj uspostavljanje kredibilnih evropskih bezbednosnih struktura aktuelizuje se problem bezbednosne dileme o primarnoj nameni vojnih potencijala tih asocijacija. Takva okolnost, kao snažna reafirmacija geopolitičkog pristupa u međunrodnoj politici pospešuje proces dalje militarizacije međunarodnih odnosa, kao i jačanje vojnih potencijala u državama koje nisu uključene u te asocijacije.

Iako su nakon trijumfa u Hladnom ratu najavile društvo sasvim različito od do tada poznatih društava, SAD u svom globalnom delovanju nisu se odrekle ni svojih hegemonističkih aspiracija niti imperijalnog nasleđa evropskih država ${ }^{13}$. Svoju globalnu upravljačku ulogu i dominnatnu poziciju u svetskoj politici, SAD su gradile na jasno prepoznatljivim realpolitičkim principima i geopolitičkim inetresima koji svoje polazište imaju u moći i nastojanju da se ona u međunarodnoj politici neprestano potvrđuje. Upravo zato, SAD su svoju poziciju globalnog hegemona nastojale da institucionalizuju stavranjem mreže međunarodnih organizacija, kao što su Svetska banka, Monetarni fond, Svetska trgovinska organizacija, čime su obezbedile presudan uticaj u kreiranju dugoročnih okvira globalne ekonomske politike. Podređenost Evrope i njena opredeljenost da svoju

\footnotetext{
11 Danilović Neđo, Gordić Miodrag (2015): Savremeni sistemi bezbednosti, Zavod za udžbenike, Beograd, 26

12 Falk Ričard, 68.

13 Bežežinsk Zbignjev (2013): Amerika - Kina i sudbina sveta, Albatros Plus, Fakultet bezbednosti, Beograd, 13.
} 
bezbednost veže za SAD, institucionalizovana je stvaranjem NATO, pri čemu ni Ujedinjene nacije nisu mogle da ostanu po strani tih procesa, pa je i njihovo funkcionisanje instrumentalizovano za potrebe jedne sile. Time su SAD definisale globalni institucionalni okvir od vodećih međunarodnih organizacija što im je omogućilo da prolongiraju svoju dominaciju i privlegovanu poziciju u distribuciji svetskog bogastva. Takvi hegemonistički vrednosni postulati spoljnopolitičkog delovanja onemogućili su SAD da svoju dominantnu ulogu iskoriste konstruktivno i da promovišu dobro upravljanje svetom ${ }^{14}$, već je takva, iritirajuća politika uvećavala globalnu nestabilnost i nebezbednost. Ispostavilo se, kao tvrdi Bžežinski, da je globalna politika nespojiva sa koncentracijom hegemone moći u rukama jedne jedine države ${ }^{15}$.

Dometi razvoja globalnog društva potvrđuju, kako ispravno zapaža Kejgan, da veliku zabludu našeg vremena predstavlja teza da liberalni međunarodni poredak počiva na trijumfu ideja i na prirodnom odvijanju ljudskog progresa ka miroljubivj koegzistenciji ${ }^{16}$. Proces globalizacije sve više suočava ljude sa uznemirenim, nesigurnim, nepredvidivim i rizičnim svetom. Pokazalo se da su globalni procesi bili neuspešni u stvaranju uslova ka konstituisanju jedinstvenog političkog, ekonomskog i kulturološkog prostora, kao i da su svojim asocijalnim tendencijama izazvali izražene polarizacije, socijalne, političke, verske i etničke tenzije i sukobe. Bezbednost kao jedan od prmarnih ciljeva globalnog upravljanja svetom nije, kao se na početku procesa velike transformacije sveta najavljivalo, unapređena, već su nebezbednost i nesigurnost postali snažna određenja individulane i kolektivne egzistencije savremenih ljudi.

\section{Ograničenja globalnog upravljanja}

Aktuelni proces globalizacije nije se potvrdio u sferi globalnog upravljanja, a slabljenje dometa ideje liberalnog globalnog društva potvrđuje da se odnosi koji preovaladavaju u međunarodnoj politici ne menjaju brzo, odnosno, umesto toga, oni su, kako zapaža Volc, zastrašujuće trajni ${ }^{17}$. Kontinuitet obrazaca međunarodne politike potvrđuje neprolaznu aktuelnost Tukidovih shvatanja o moći kao dominantnom načelu u međunarodnoj politici.

Istovremeno, teško je osporiti činjenicu da je proces globalizacije aktuelizovao i snažno promovisao ideju o poželjnosti, ili čak nužnosti efektivne svetske vlasti. Ogroman tehnološki razvoj, posebno razvoj informacione tehnologije, podstakao je snažan proces homogenizacije sveta, smanjujući razlike i ujedi-

\footnotetext{
Falk Ričard, 60.
}

15 Bžežinski Zbignjev, 13.

16 Kejgan Robert, 97.

17 Volc Kenet (2008): Teorija međunarodne politike, Centar za civilno-vojne odnose, Beograd, 76.

Vol. 13, № 2, 2016: 133-148 
njujući ga kao nikad ranije. Impresivno smanjenje razlika i radikalno povećana međuzavisnost između pojedinaca društvenih grupa i političkih društva upućuje na sve izraženiju jedinstvenost sveta i nameće sve veći broj denacionalizovanih pitanja $^{18}$. Istovremeno, sa porastom pitanja koja zahtevaju globalno rešavanja sve su brojnije i ljudske delatnosti koje podrazumevaju jedinstvenu ili međunarodnu regulaciju, jer svet je sve više jedna homeostataska celina međuzavisnih delova gde mnogi aspekti granica izemđu država su teško održivi ili čak nemogući ${ }^{19}$. Otuda značaj globalnih činilaca, od kojih će u punoj meri zavisiti artikulacija individualnog i zajedničkog života ljudi u budućnosti, apostrofiraju važnost pitanja zajedničkog upravljanja koje treba da obezbedi globalni mir i pospeši blagostanje širom sveta na jedan univerzalno prihvatljiv i efikasan način ${ }^{20}$.

Dosadašnje istorijsko iskustvo ne daje osnove za optimizam u pogledu mogućnosti dostizanja trajne legitimnosti svetske vlasti. Prisutna su brojna ograničenja i teškoće koje prate ideju o političkom ujedinjavanju sveta, a promovisanje univerzalnih vrednosti i asimilacija u jedan jedinstven kulturni obrazac praćeno je snažnim tendencijama diskavalifikovanja različitosti. Otuda, uporedo sa tendencijom globalne harmonizacije svetske politike, odvijao se proces retradicionalizacije i nastajanja promena i razlika suprotan osnovnom smeru globalizacije. Takva stremljenja koja primarno naglašavaju značaj identitetskih određenja, koja dobijaju na intenzitetu, ukazuju da globalizovani svet, onakvog kakvog ga sada vidimo nije jedan već je skup mnogih posebnih svetova specifičnih identiteta. Danas je evidentno da savremena ideja globalne političke zajednice, koja nužno pretpostavlja određeni kolektivni identitet i saglasnost u artikulaciji univerzalnih društvenih normi i standarda, nije, između ostalog, uspela da neutrališe različitost koja se pokazala jačom od bilo koje univerzalističke ideje. Zato je svet danas daleko od globalne političke zajednice već predstavlja jedan skup ili agregat različitih delova sa različitim ciljevima i vrednosnim percepcijama ${ }^{21}$.

I pored krajnje onespokojavajućih rezultata procesa globalizacije, prisutno je uverenje da jedino svetska vlast koja raspolaže delotvornim mehanizmima moći, može da obezbedi prevazilaženje anarhije u međunarodnoj politici i osigura istinski svetski mir i trajnu stabilnost sveta ${ }^{22}$. U prilog takvom stavu navodi se argumentacija da bi uspostavljanjem svetske države konačno asocijalni potencijali ljudske prirode i njihovih asocijacija bili stavljeni pod kontrolu i da bi se kroz artikulaciju univerzalnih normi i uspostavljanje globalnog društvenog reda omogućila validna distribucija moći i tako obezbedili okvire za uspostavljanje globalnog mira. Tako Vendt smatra da priroda odnosa u međunarodnpoj politici čini neminovnim uspostvljanje globalnog monopola na legitimnu upotrebu

\begin{tabular}{ll}
\hline 18 & Cirn Michael, 402. \\
19 & Babić Jovan, Bojanić Petar. \\
20 & Ibid. \\
21 & Ibid. \\
22 & Ibid.
\end{tabular}


organizovanog nasilja. Naime, logika anrhije u medjunarodnoj politici, kako misli Vendt, čije su posledice porast destruktivnosti vojne tehnologije i rata čini u skorijoj budućnosti neminovim nastanak svetske države ${ }^{23}$.

Podeljena su mišljenja oko mogućnosti zasnivanja svetske vlasti kao pretpostavke za trajan mir i bezbednost. Poznato je da je Hobs osporavao ideju globalne zajednice, jer je smatrao da je prirodno stanje kao stanje sveopšteg sukoba neotkolonjivo u međunarodnoj politici, pa je za njega svetske vlast - nerealna opcija. Na pozicijama bliskim Hobsovim stoje i oni teoretičari koji smatraju da je različitost sveta jača od bilo kog ujedinjujućeg procesa. Tako je moć razlikovanja za Rodrika osnov njegove sumnje u mogućnost globalnog upravljanja, jer u svetu postoje previše raznolikosti da bi narodi mogli da budu obuhvaćeni zajedničkim pravilima i da budu uklopljeni u jednu političku zajednicu ${ }^{24}$. Prema njegovom mišljenju, ta činjenica određuje domete i granice globalnog upravljanja zbog čega je kategoričan u stavu da još uvek nacionalne države nadvladavaju sve druge oblike identiteta ${ }^{25}$.

Naravno, ima teoretičara koji smatraju da bi globalna vlast u priličnoj meri bila nalik postojećim nacionalnim državama i da bi kao takva patila od brojnih nesavršenosti. Naime, svoju rezevu prema globalnoj vlasti zasnivaju, pre svega, na stavu da je svaka država zbog svojih ambicija da kontroliše i ograničava ljudske slobode sama po sebi zlo, pa bi sami tim globalna država sa globalnim dometima kontrole potencijalno bila još veće zlo. Drugim rečima, kako smatra Narveson, svetska vlast bi imala sve one loše osobine postojećih nacionalnih vlasti, ali u mnog većoj meri ${ }^{26}$.

Kao posebno teško rešiv problem javlja se demokratski legitimitet globalne vlasti, kao i institucionalna artikulacija kosmopolitske prirode svetske vlade. Danas ne postoje uverljive ideje o trajnoj legitimnosti svetske vlasti ${ }^{27}$, odnosno, o načinu kako ustrojiti dovoljno reprezentativnu vlast na svetskom nivou. Isto tako, ozbiljnu teškoću predstavlja uspostavljanje jedinstvene pravne regulative koja podrazumeva potrebu za jedinstvenim centrom moći i političkim autoritetom koji može da osigura njeno univerzalno važenje, kao i efikasno suočavanje sa problemima koji imaju globalne zahvate. U vezi sa tim, kao teško rešiv problem pojavljuje se problem pristanka na globalnu vlast, imajući u vidu da je važna pretpostavka validnosti predstavničke demokratije, koja se smatra opštim modelom legitimnosti, njeno slobodno prihvatanje. Naravno, univerzalna zako-

\footnotetext{
23 Wendt Alerxander (2003): „Why a World State is Inevitable”, European Journal of International relations, Vol. 9(4) 491-542

24 Rodrik Deni (2013): Paradoks globalizacije, Službeni glasnik, Beograd,174.

25 Ibid, 195.

26 Narveson Jan, „Da li se svetska vlast može sprovesti na dobar način? Teško”. u: Babić Jovan, Bojanić Petar, Zbornik Globalno upravljanje svetom, Pravni fakultet Univerziteta u Beogradu, Dosije studio, Beograd, 50.

27 Babić Jovan, Petar Bojanić, 13.
} 
nodavna regulativa koja bi bila slobodno prihvaćena i koja bi obezbedila primenu globalnih normi podrazumeva i određeni kolektivni identitet, što otvara pitanje globalnih vrednosnih opredeljenja.

Međutim, stav koji je u raspravi o mogućnosti uspostavljanja svetske vlasti nedvosmislen jeste da svetska vlast mora primarno da bude rezultat saglasnosti, a ne straha i prinude, što znači da mora da pretpostavlja i određeni vrednosni identitet. U tom kontekstu kao značajan argument uzima se Kantovo zalaganje za uspostavljanje jedne neprisilne lige država i njegov stav da država ima pravo da ne bude prisiljena da bude uključena u jedinstvenu političku strukturu sa obavezujućim univerzalnim zakonima ${ }^{28}$.

Proces globalizacije, što je danas jasno, diskreditovao je ideju globalne uprave i pojedine dileme o tome da li su određeni sadržaji globalnog upravljanja mogući su još više zaoštrene. Praksa uspostavljanja globalnog društva nedvosmisleno nameće zaključak da su hegemonistički pristupi zagovornika globalizacije bili preovlađujući u njihovim nastojanjima da se bez ostataka univerzalizuje iskustvo liberalnog modela društvene organizacije. Svetsko društvo je snažno hijerarhizovano, a aktuelan poredak je usavršio i institucionalizovao mehanizme eksploatacije ljudi i prirodnih resursa. Imperijalne tendencije SAD, koje slabljenjem globalnih procesa i pojavom novih globalnih aktera u međunarodnoj politici gube na intenzitetu, i dalje se svode na političko i vojno obezbeđivanje svetskog tržišta čije neprestano širenje ostavlja sve manje prostor za suverene države ${ }^{29}$. Globalni trendovi su potvrdila Brodelov stav da se tokom istorije osnovno načelo sveta nije izmenilo, on je i dalje podeljen na one koji su povlašćeni i one koji nisu povlašćeni.

Velika finansijska kriza iz 2008. godine, koja je bila izazvana neodgovornim aktivnostima u oblasti bankarstva i finansija i koja je dala dramatičnu dimenziju teškoćama sa kojima se suočava savremeni svet, podstakla je ozbiljna pitanja o održivosti globalne ekonomije, kao pokretačke sile globalnog društva i podstakla već ozbiljno načetu eroziju legitimiteta međunarodnih organizacija. Rodrik naglašava da za razliku od nacionalnih tržišta, kojima domaće regulatorne političke institucije obično pružaju oslonac, globalna tržišta su neuklopljena, nema globalnog regulatornog tela, a naravno ni globalne demokratije. Drugim rečima, globalna tržišta pate od slabog upravljanja, te su stoga sklona nestabilnosti, neefikasnosti i slabom javnom legitimitetu ${ }^{30}$. Ova neravnoteža između nacionalne kompetencije vlade i globalne prirode tržišta predstavlja posebno slabu tačku globalizacije. Zdrav globalni ekonomski sistem zahteva delikatni kompromis između te dve sfere, naglašavajući da tržište nije najbolje tamo gde su države najslabije, već gde su najjače ${ }^{31}$. To znači da tržišta zahtevaju normativnu uređe-

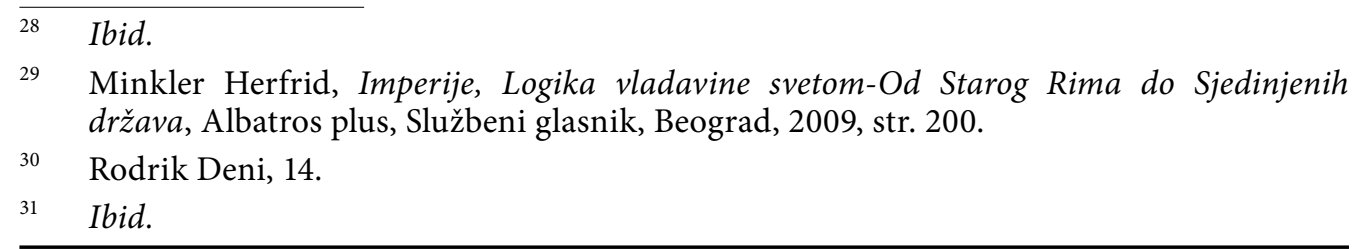


nost $\mathrm{i}$ instiucionalnu izgrađenost, naglašavajući da proizvodnja ne mora da bude globalna da bi bila uspešna ${ }^{32}$.

Za Stiglica, takođe, nema sumnje da efekti globalizacije nisu bili u funkciji stabilnosti i bezbednosti sveta. Međutim, za njega, kao i za veliki broj drugih teoretičara, problem nije u globalizaciji, već u tome kako se njome do sada upravljalo ${ }^{33}$. On je kategoričan u stavu da proces globalizacije nije ni otvoren ni pravedan jer u okviru njega nema jasnih institucija i pravila, a ne postoji ni sistem odgovornosti. $U$ vezi s tim, on posebno ukazuje na manjkavosti sistema upravljanja međunarodnim ekonomskim i finansijskim institucijama, zalažući se za donošenje pravila ponašanja multinacionalnih korporacija i finansijskog kapitala i veću odgovornost, otvorenost i veću kontrolu MMF-a i Svetske banke.

Iako veliki broj teoretičara sumnja u mogućnost demokratske uprave na transnacionalnom nivou, smatrajući da je demokratski legitimitet moguć samo u okviru države, jedan broj teoretičara međunarodnih odnosa demokratsku globalnu upravu smatra mogućom. I Habermas smatra da su asocijalne tendencije neoliberalne politike, kao i demokratski deficiti koji prate globalne procese ključna ograničenja za uspostavljanje prihvatljivog sistema globalnog upravljanja svetom. Međutim, prema njegovom mišljenju teško je zamisliti novi milenijum kao svet samodovoljnih nacionalnih ekonomija jer nas globalni procesi navikavaju „korak po korak, na jednu novu perspektivu, iz koje jasnije nego ranije uočavamo kako su socijalne pozornice veoma ograničene, da su rizici zajednički i da su kolektivne sudbine umrežene" ${ }^{34}$. Habermas smatra da bi alternativa asocijalnim tendencijama neoliberalne politike bile radikalne izmene u funkcionisanju postojećih globalnih ekonomskih instiucija i demokratizaciju pravila i procedura u njihovom odlučivanju. Za njega, ali ne samo za njega, uspostavljanje kosmopolitske demokratije, ključna je pretpostavka za stvaranje ambijenta u kojem bi bila moguće globalno društvo s humanijim likom. U osnovi tako kosmopolitski organizovane zajednice stajala bi saradnja i svest o nužnosti kosmopolitske solidarnosti.

Held najveće nedostatke globalnih procesa vidi u pomanjkanju njihove demokratske utemeljenosti, posebno demokratskog odlučivanja u nadnacionalnim institucijama. Svakako, fundamentalna promena u toj sferi tiče se uspostavljanja globalnog demokratskog zakonodavstva kao okvira delatnosti korporacija koji treba da omogući da se njihova aktivnost i ekonomski uspeh ne zasnivaju na razaranju prirode, blagostanja i zdravlja ljudi. Njegova koncepcija kosmopolitske demokratije zasnovana je na utemeljenju demokratskog prava u međunarodnoj sferi ${ }^{35}$.

$\mathrm{Na}$ brojne strukturne probleme koji prate ideju globalne uprave ukazuje i Cirn, koji posebno naglašava snažan uticaj globalizacije na brojne aspekte savremenih međunarodnih odnosa. Prema njegovom mišljenju, globalni procesi, pre-

$32 \quad$ Ibid, 200.

33 Stiglic Džozef (2002), Protivrečnosti globalizacije, SBM-x, Beograd, 225.

34 Habermas Jirgen, 60.

35 Held Dejvid (1997), Demokratija i globalni poredak, Filip Višnjić, Beograd, 262.

Vol. 13, № 2, 2016: 133-148 
vashodno supranacionalizacija, transnacionalizacija i decentralizacija slabe legitimitete nacionalnih politika i menjaju prirodu suveriniteta čime ultimativno transformišu fundamentalne strukture međunarodne politike od anarhije ka sistemu globalne uprave ${ }^{36}$. Naime, prema njegovom mišljenu globalno upravljanje je moguće, ali nadnacionalna vlast bi se suočavala sa spornim legitimiteteom monopola korišćenja sile, što bi ograničavalo njene sposobnosti globalnog delovanja. Smatrajući da socijalna denacionalizacija, kao posledica transnacionalnog karaktera globalnih procesa, zahteva drugačije osobine međunarodnih institucija, on naglašava da su neophodne moćne međunarodne organizacije. Razmatrajući teorijski okvir globalne uprave na više nivoa (global multi-level governanace), Cirn ukazuje na nezaobilazne strukturne probleme takve uprave, posebno ističući probleme saglasnosti, koordinacije, legitimiteta, politizacije medjunarodnih institucija i fragmentacije, koji bi limitirali njene domete ${ }^{37}$.

Naravno, posebno snažno ograničenje u definisanju održivih okvira globalne uprave danas predstavlja sve izraženije razilaženje sveta. Slabljenje ideje globalnog zajedništva, a samim tim i ideje o nedeljivosti bezbednosti, potiskuju modele partnerstva i zajedničkog delovanja kao važnih pretpostavki za adekvatne odgovore na transnacionalno profilisane pretnje bezbednosti. Povratak istorije $\mathrm{u}$ međunarodnu politiku otvara prostore za stare i novonastale ideološke i druge animozitete i pospešuje nove podele, a samim tim i nova bezbednosna pregrupisavanja. Odsustvo jasno demokratski definisanih procedura, zanemarivanje međunarodnog prava, kao i manjkav legitimitet i vitalitet Ujedinjenih nacija kao univerzalne međunarodne organizacije predstavljaju realnu opasnost od nelegitimnog angažovanja vojnih efektiva nadnacionalnih bezbednosnih asocijacija, kao i vojnih efektiva najmoćnijih država i ugrožavanja bezbednosti u svetu. Takav kontekst ukida mogućnost institucionalizacije globalnog upravljanja svetom.

\section{Zaključak}

Globalizacija nije transformisala svet, a koncept globalnog upravljanja svetom pokazao se kao neuspeli pokušaj, ispoljivši brojne sistemske disfunkcionalnosti. Turbulentni ekonomski trendovi, geopolitička situacija koja je možda opasnija od bilo koje druge situacije od Drugog svetskog rata, haos i ekstremizam na Istoku, dezorijentisana i oslabljena Evropa i sve izraženije hijerarhizovanje sveta na one koji imaju i na one koji nemaju, predstavljaju dominantna obeležja koncepta globalnog društva u pokušaju. Umesto globalnog zbližavanja, što je bila noseća ideja globalnih procesa, savremeni svet se suočava sa procesom intenzivnog globalnog razilaženja, a multikultilarni koncept globalne zajednice ugrožen je nametljivim ideološkim univerzalizmom, za koji nema stvarnog pokrića u

\footnotetext{
36 Cirn Michael, 408.

37 Cirn Michael, 412-416.
} 
smeru kretanja socijalnih, ekonomskih i kulturoloških tokova u svetu. Sve to ukazuje da je savremeni svet krenuo suprotnim smerom dajući prednost takmičenju, a ne saradnji, a da globalni poredak trajno institucionalizuje nejednakost, čineći globalni mir i stabilnost teško dostižnim.

Snažno slabljenje ideje globalnog društva i porast divergentnih procesa reaktuelizuje realpolitički pristup u međunarodnoj politici. Eskalacija konflikata u arapskom svetu, građanski rat u Libiji kontraverzni događaji u Siriji, kao i dešavanja u Ukrajini nagoveštavaju povratak tradicionalnih principa u praktikovanju bezbednosti. Isto tako, odsustvo zajedničke vizije, kako graditi pouzdanu glbalnu bezbednosnu strukturu i sve snažniji hladnoratovski stereotipi devalviraju postmoderne koncepte bezbednosti koji u osnovi podrazumevaju saradnju i zajedničko delovanje u upravljanje bezbednošću sveta. Sve to nameće ozbiljna iskušenja u pogledu činjenice da tehnološki trendovi razvoja i sve veća međuzavisnost sveta umnožavaju broj transnacionalnih ugrožavanja bezbednosti koja zahtevaju integrisane i koordinisane odgovore i tako šire prostore globalne uprave . 


\section{Literatura}

- Babić Jovan, Bojanić Petar (2012): Zbornik radova, Globalno upravljanje svetom, Pravni fakultet Univerziteta u Beogradu, Dosije studio, Beograd.

- Bžežinski Zbignjev (2013): Amerika - Kina i sudbina sveta, Albatros Plus, Fakultet bezbednosti, Beograd.

- Bek Urlix (2001): Rizično društvo, Filip Višnjić, Beograd.

- Volc Kenet (2008): Teorija međunarodne politike, Centar za civilno-vojne odnose, Beograd.

- Danilovic Nedjo, Gordić Miodrag, Blagojević Srdjan (2015): Savremeni sistemi bezbednosti, Zavod za udžbenika, Beograd.

- Kejgan Robert(2009): Povratak istorije i kraj snova, Centar za civilno-vojne odnose, Beograd.

- Minkler Herferd (2009): Imperije, Logika vladavine svetom-Od Starog Rima do Sjedinjenih država, Albatros plus, Službeni glasnik, Beograd.

- Rodrik Deni (2013): Paradoks globalizacije, Službeni glasnik, Beograd.

- Sol R. Džon (2011): Propast globalizma i preoblikovanje sveta, Arhipelag, Beograd.

- Stiglic Džozef (2002): Protivrečnosti globalizacije, SBM-x, Beograd.

- Stiglic Džozef (2013): Slobodan pad-Amerika, slobodna tržištai slom svetske privrede, Akademska knjiga, Novi Sad.

- Stojanović Stanislav (2009): Globalizacija i bezbednosne perspektive sveta, VIZ, Beograd.

- Cirn Mihael (2003): Upravljanje s one strane nacionalne države, Filip Višnjić, Beograd.

- Cirn Michael (2013): «Globalization and global governance», Handbook of International relations, Edited by W.Carlsnaes, T. Risse, B.A.Simmons, SAGE, London, 401-427

- Habermas Jirgen (2002): Postnacionalna konstelacija, OTKROVENJE, Beograd.

- Hantington Semjuel (1999): Sukob civilizacija i preoblikovanje svetskog poretka, CID Podgorica.

- Held Dejvid (1997): Demokratija i globalni poredak, Filip Višnjić, Beograd.

- Wendt Alexander (2003): „Why a World State is Inevitable”, European Journal of International relations, Vol. 9(4): p 491-542 


\author{
Prof. Stanislav Stojanović, PhD \\ Strategic Research Institute, Belgrade \\ Prof. NeĐo Danilović, PhD \\ The Faculty of Law, University "John Naisbitt", Belgrade
}

\title{
GLOBALIZATION AND DEFICIT AND LIMITATIONS OF GLOBAL GOVERNANCE
}

Abstract: Character and dynamics of relationships in international politics, in which the stronger return to real politics content in the functioning of the foreign policy of the great powers, unequivocally affirms that globalization does not work to its declining power that is less credible design concept of modern world society. The global financial collapse that hit the world in 2008 is a convincing indication that most of the globalization is discredited. The belief in one humanity is becoming a less desirable concept.

At the same time, with the increase in global issues that require solving, there are numerous human activities that involve unique or international regulation. The world is increasingly one homeostatic system of interdependent parts of a continent where many aspects of the borders between countries are difficult or even impossible to sustain. Hence the importance of global factors, some of which will fully depend on the articulation of individual and community life of people in the future, stressing the importance of the issue of joint management to ensure global peace and security and promote the prosperity around the world in a universally acceptable and effective way.

Therefore, the demonstrated substantial shortcomings of global governance of the world, although they discourage belief in humanity, did not reduce the objective need for global access to many amenities of modern human existence. Many aspects of security, ranging from the security of the individual to the energy and environmental security in modern conditions are not conceivable without international access. However, global security management has been associated with numerous limitations and challenges.

Keywords: globalization, global society, the limitations of global governance of the world, the world risk society, global security management. 